\title{
The Effects of Alcohol on Oral Health, a Review
}

\author{
Antonia Ivoš ${ }^{1}$, Ana Matošić ${ }^{2}$, Ivan Pavao Gradiški ${ }^{3}$, Ivona Orlović ${ }^{4}$ \\ ${ }^{1}$ University of Zagreb, School of Dental medicine, Zagreb, Croatia, ${ }^{2}$ Department of \\ Psychiatry, University Hospital Centre Sestre Milosrdnice, Zagreb, Croatia, ${ }^{3}$ University Psy- \\ chiatric Hospital Vrapče, Zagreb, Croatia, ${ }^{4}$ Institute of Public Health, Međimurje County, \\ Čakovec, Croatia
}

\begin{abstract}
Drinking alcoholic beverages is one of the oldest socially acceptable forms of behavior which can lead to the development of alcohol addiction. Long-term alcohol drinking has, together with numerous psychological and somatic complications, harmful consequences for the oral health. Patients suffering from alcoholism generally have poorer oral hygiene, dental care, periodontal status, fewer teeth, more carious lesions, gingival diseases, inter-dental papillae bleeding and deep gingival pockets associated with bone loss, as well as higher rate of oropharyngeal cancer. The changes in the oral microbiome affect the immune system, metabolism of carcinogens and digestion, which also leads to the development of local oral diseases as well as systemic gastrointestinal and cardiovascular illnesses.

Harmful impact of alcohol on oral health can be direct, caused by local toxic effects of alcohol and as a consequence of systemic diseases associated with alcohol drinking, causing changes in the entire oral mucosa. Poor dietary habits additionally contribute to a poorer dental status while frequent simultaneous usage of tobacco products additionally increases the risk of developing periodontitis, tooth loss and oral carcinoma. Excessive alcohol drinking can seriously affect the oral cavity where, despite easy access via clinical examination, we still lack clinical data and a clear mechanism of development of the described changes.
\end{abstract}

Key words: alcohol, alcoholism, oral health, oral diseases, public health

Copyright @ 2019 KBCSM, Zagreb

e-mail: alcoholism.kbcsm@gmail.com•www.http://apr.kbcsm.hr

\section{Introduction}

Drinking alcoholic beverages is one of the oldest forms of socially acceptable behavior which may result in alcohol addiction, one of the leading public health issues [1]. According to the extent of drinking and habits we

Correspondence to: Ana Matošić

Department of psychiatry, University Hospital Center Sestre Milosrdnice, Zagreb, Croatia differentiate social (controlled) drinking, alcohol abuse and alcohol addiction. Alcohol abuse, usually presented with health consequences, may develop into alcohol addiction, which is characterized by alcohol cravings, loss of control over drinking, physical symptoms of withdrawal in case of drinking cessation, rise of alcohol tolerance, increase in the consumed amount, disregard for other interests and continuation of drinking in spite of awareness on harmful consequences. Alcohol addiction is two to three times more 
common in men than in women [2]. According to the World Health Organization the average annual consumption of alcoholic beverages in Croatia is 12.9 liters of pure ethanol per adult person. Around $90 \%$ of adult men and $80 \%$ of adult women drink alcohol, out of which $15.7 \%$ are considered at risk [3].

Ethanol is largely absorbed through the gastric and duodenal mucosa and metabolized by the liver with only a smaller fraction being metabolized locally in the oral, gastric and other mucosae of the upper digestive tract. The enzymes acetaldehyde dehydrogenase $(\mathrm{ADH})$ and alcohol dehydrogenase $(\mathrm{ALDH})$ are catalysts for ethanol oxidation in the described first pass metabolism [4].

Alcohol dependence is often associated with other psychiatric disorders and linked to a change in behavior that often involves a tendency towards risky situations, followed by auto- and hetero- destructiveness as well higher likelihood of accidents [5, 6]. Excessive drinking also leads to numerous somatic complications and conditions, including consequences on oral health. Research has shown that heavy drinkers have poorer oral hygiene, dental care, periodontal status, fewer teeth, more carious lesions, gingival diseases, interdental papillae bleeding and deep gingival pockets connected with bone loss as well as a higher rate of oropharyngeal cancers [7-10]. Non-carious destructions of teeth, including dental erosions, are also linked to frequent drinking due to presence of polyphenols in most alcoholic beverages which leads to precipitation of proline-rich proteins in the saliva [11]. The high concentration of acids in alcoholic beverages can cause chronic inflammation of the oral soft tissues and negatively affect the metals in various orthodontic devices. It's important to accentuate that around $80 \%$ of alcohol addicts are also heavy smok- ers [12]. In tobacco smokers ethanol increases the permeation of tobacco carcinogens by increasing membrane permeability of the oral mucosa epithelial cells [13]. Poor dietary intake of fruits and vegetables, which is also common in heavy drinkers, can facilitate the onset of such conditions. Furthermore, alcohol has a cytotoxic effect on bacteria, changes the saliva-bacterium interactions and enables ethanol as a substrate for bacterial metabolism [14]. Consequently, the change in the oral microbiome has effects on the immune system, metabolism of cancerogens and digestion $[15,16]$ which leads to local oral diseases [17] and possibly systemic gastrointestinal and cardiovascular diseases $[17,18]$.

The authors aimed to present a systematic overview of the present scientific data regarding the effects of alcohol on the oral cavity and oral health.

\section{The effects of alcohol on oral health}

Based on the action mechanism harmful consequences of alcohol consumption on oral health can be divided into direct, caused by local toxic effects of alcohol, and consequences of systemic disorders associated with alcohol drinking. All of the below mentioned changes in the oral cavity can affect self-confidence as presented in the research of Jelić and associates, which has also revealed a poorer oral status in people with an alcohol use disorder compared to the control group [19].

\section{The direct effects of long-term alcohol drinking}

\subsection{The effect of long-term drinking on the saliva and teeth}

Immediately after alcohol ingestion ethanol diffuses into the salivary glands and sali- 
va where initial alcohol concentrations reach higher values compared to blood values. After thirty minutes, alcohol concentrations in saliva match blood concentrations which indicates successful perfusion in all surrounding tissues, including oral mucosa, major and minor salivary glands. Upon cessation of drinking the level of acetaldehyde in the saliva significantly risesand surpasses blood level concentrations. Consequently, the oral cavity retains large concentrations of this toxic molecule for a long period of time, which damages mucosal and glandular tissues, reducing their immune functions, making mucosa more prone to microbial penetration [20, 21].

Long-term alcohol drinking can lead to peripheral neuropathy, which is connected to sialadenosis, edema of salivatory glands, especially parotid glands [22, 23]. Sialadenosis results in a disturbance of salivary glands metabolism and excretion [23]. Reduction of salivatory glands excretion and neglection of oral hygiene coupled with consumption of foods rich in carbohydrates causes a salivary $\mathrm{pH}$ decrease below the critical level, thus increasing the risk of caries and gingival diseases [24, 25].

Consumption of acidic beverages, such as wine, makes the oral cavity and the teeth surface acidic and sensitive to mechanical injuries during tooth brushing. This also occurs due to vomiting caused by the effect of alcohol on the esophageal sphincter and reduced salivation. Such acidification increases the risk of erosion [11]. There is a high incidence of tooth decay in alcohol addicts, up to three times higher than in people who abstain from drinking alcoholic beverages or drink them rarely [26]. The incidence of dental caries in alcohol addicts is more than double, with trebled incidence of permanent tooth loss [7, 26] Furthermore, they also have an increased risk of periodontal diseases which is associated with gingival tissue irritation, poor oral hygiene and dental care, poor dietary habits causing immune depletion and bacterial deposition due to lack of saliva and dehydration $[8,27]$ as well as a serious risk for the development of chronic generalized periodontitis associated with interdental papilla and gingiva inflammation together with formation of periodontal pockets associated with bone loss [27, 28].

\subsection{The effects of long - term drinking on the tongue}

Alcohol can cause glossitis (inflammation of the tongue), gingivitis (inflammation of the gingiva), and sometimes angular cheilitis (inflammation of the corners of the mouth). In the early stages of glossitis the tongue is painful and swollen while in later stages it becomes extremely red followed by burning sensations with filiform and fungiform papillae atrophy on the tongue surface. Gingivitis is manifested by necrotic areas at the top of the interdental papilla while angular cheilitis is characterized by painful fissures and cracks in the corners of the mouth. The use of disulfiram can also alter taste sensation, often causing a metal taste in the mouth [27].

\subsection{Oral manifestations caused by the direct effect of alcohol on the oral mucosa}

Many studies confirm that alcohol intake increases the risk of developing cancer of the oral cavity. The risk is further increased if alcohol is combined with smoking tobacco [29]. The systemic effects of alcohol joined with local changes in the morphology of the mucous membranes and glands form the basis for the accumulation of microorganisms and the development of chronic infections, although the direct link between alcohol and precancerous lesions remains unknown [10]. 
It is assumed that exposure to many carcinogens found in alcoholic beverages encourages carcinogenesis and proliferation mucosa cells leads to genetic changes and development of precancerous lesions (leukoplakia and erythroplakia) and carcinoma [28].

\subsubsection{Leukoplakia}

Oral leukoplakia is the most common precancerous lesion with tobacco and alcohol as the main etiological factors, followed by mechanical irritation, syphilis and candidiasis. According to clinical studies, the most common location of malignant transformation of leukoplakia is the oral cavity floor. First symptoms of this change are erythema, edema, and thickening of the mucous membrane that eventually becomes white or gray. The mucosal surface may be smooth or wrinkled and in the same level as the surrounding mucosa or above it. The lesion also may be streaked with red or normal mucous membranes. In most cases, leukoplakia is asymptomatic $[10,31]$.

\subsubsection{Erythroplakia}

Erythroplakia is a relatively rare oral cavity lesion with very high malignant potential [32]. Clinically, it appears as a flat or slightly elevated red lesion in the oral mucosa, sometimes associated with leukoplakia [33]. It is mainly located in the bottom area of the oral cavity, soft palate, the ventral side of the tongue and buccal mucosa. Usually, it is asymptomatic, although some patients report burning sensations. Most of the samples show a high level of expression of epithelial dysplasia and in situ or invasive carcinoma.

Frequent consumption of alcohol and tobacco is considered to be an etiological fac- tor. The diagnosis is set by a clinical examination and confirmed by biopsy. It is treated with surgical ablation and avoidance of etiologic factors $[32,34]$.

\subsubsection{Oral cancer}

Alcohol, especially combined with tobacco, is an important risk factor for the development of a carcinoma of the oral cavity and is commonly associated with about $75 \%$ of upper digestive tract cancer $[35,36]$. All types of alcohol, including spirits, wine and beer, are associated with oral carcinoma [20]. A study from 2010 showed that people who drank four or more alcholic beverages a day had a five times higher risk of oral cancer compared to teetotalers or people who rarely consumed it [37]. Synergism of alcohol and smoking increases this risk by alcohol-mediated increased permeability of the oral mucosa for carcinogenic components of tobacco smoke [36]. The risk of developing oral cavity carcinoma is increased by up to a hundred times in people who consume one hundred grams of alcohol per day and smoke twenty or more cigarettes a day [29]. Although the carcinoma is most common between the ages of 50 and 70, the risk is not related to age but solely on the amount of ingested alcohol [38]. However, all people who drink will not develop oral cancer; even the role of alcohol in its development remains unknown.

Certain carcinogenic effects of alcohol may play a role in the pathogenesis of oral cancer, i.e. the dehydrating effect of alcohol on the cell increases the mucous permeability to other toxins and carcinogens; ethanol-mediated changes in mucous morphology and production of acetaldehyde which causes damage to oral epithelial cells DNA and oncogene expression of oral keratinocytes; dam- 
aging the functioning of the salivary gland by reducing secretion of the epidermal growth factor that protects the oral mucosa from acid-induced injuries which therefore increases the risk of oral mucosal ulceration; nutrient deficiency prevents the use of antioxidants in the prevention of cancer formation [39]. The most common oral cavity carcinoma is planocellular carcinoma, which has a high mortality rate since it is usually diagnosed in the advanced stage. The primary lesion in the oral cavity cancer is erythroplakia which is most often completely asymptomatic [32]. The first symptoms for which the affected persons seek help are discomfort and burning sensations in the mouth followed by difficulty swallowing, loose teeth or persistent bleeding. These symptoms usually indicate that the disease has already progressed and is in the advanced stage. The initial lesions appear in the form of a well defined mucosal erythema with a velvety or smooth surface, with or without the presence of white lesions. Carcinoma later changes to ulceration. A less common clinical picture of oral cavity carcinoma is an exophytic mass without ulceration, with signs of leukoplakia [33].

The most common location of oral cavity carcinoma is the so-called horseshoe area, which includes the bottom of the oral cavity, the lateral edges and the ventral surface of the tongue, the retromolar region and the palatal arches. One of the characteristics of malignant oral cavity carcinoma is early metastasis in the area of the cervical lymph nodes. The diagnosis of oral carcinoma is based on clinical examination, biopsy and $\mathrm{x}$-rays. Treatment of oral cavity cancer is almost always surgical, in combination with radiation therapy $[40,41]$.

\section{Systemic effects of long-lasting alcohol drinking on the oral mucosa}

2.1. The changes in oral mucosa associated with cardiovascular diseases caused by long-term alcohol drinking

Long-lasting alcohol drinking has complex effects on the cardiovascular system. One of the most common toxic effects in alcohol addicts is dilatative cardiomyopathy, an illness characterised by ventricular hypertrophy and fibrosis, with gradual progression of cardiac decompensation [42]. Commonly, the first sign of cardiac decompensation is a change in the colour of oral mucosa which becomes cyanotic and the dilatation of veins on the ventral side of the tongue. Further progression of the illness can cause the development of varices. Hypertension is also perceivable among alcohol addicts and it affects the colour of oral mucosa which can be red or pale, depending on the type of hypertension. If the mucosa is red, dilatation of capillaries or teleangiectasia can also be present. Antihypertensives can often cause side effects like mouth dryness (xerostomia), swelling of the parotid gland, unpleasant taste in the mouth, gingiva hyperplasia and aphthous ulcerations of the oral mucosa $[43,44]$.

\subsection{The changes in oral mucosa associated with digestive system diseases caused by long-term alcohol drinking}

Changes in the oral mucosa can indicate changes in the digestive system. Alcohol has a direct toxic effect on the gastric and esophageal mucosa where it causes inflammatory changes (acute gastritis, peptic ulcer and esophageal reflux) which can lead to burning sensations in the oral mucosa with possible development of stomatitis (inflammation 
of the oral mucosa). Papillar atrophy can be found on the tongue with clinical presentation of glossitis exfoliativa areata migrans, a disorder characterized by areas of smooth, red depapillation which migrate on the dorsum of the tongue over time. This clinical presentation is directly connected with a disorder in gastric secretion and failure of B vitamin complex absorption, which contributes to the development of megaloblastic anemia and chronic malnutrition [40, 45]. Less frequent but also connected to alcohol intake and malnutrition is complete atrophy of the papillae on the dorsal surface of the tongue called lingua glabra. A common finding with atrophy of the papillae is distortion of the sense of taste called dysgeusia. Apart from atrophy, lingua villosa alba and nigra are also possible inflammatory changes of the tongue, characterized by elongation of the filiform papillae [40]. These changes have a defensive role, but when present for a longer period of time cause a superficial inflammation of the tongue due to accumulation of detritus, microorganisms and food residue. Recurrent aphthous ulcers (aphthae recidivans) are a common painful mucosal condition affecting the oral cavity with an autoimmune pathogenesis. Consequently to hepatobilliary diseases a tingling, burning and pricking sensation can appear together with dysgeusia. Another feature is yellowish pigmentation of the oral mucosa due to hyperbilirubinemia [40, 41].

Hepatal and pancreatic illnesses almost always present themselves with a strong foetor and appearance of oral candidiasis because of the weakening of the immune system in the oral mucosa. Rarely, following chronic liver diseases lichen planus and lichen erosivus can appear. As a consequence of liver cirrhosis development of a carcinoma of the tongue or of the floor of the mouth is possible, while consequently to hepatal failure coagulation disorders followed by bleeding inside the oral cavity are common [41].

\subsection{Changes in the oral mucosa in eating disorders and vitamin deficiencies caused by long-term alcohol drinking}

Insufficient intake of food and nutrients, vitamin deficiency, and the inability of their utilization due to various illnesses can cause severe metabolic disorders in alcohol addicts. Thus, vitamin A deficiency can contribute to the development of oral leukoplakia, which then causes increased keratinization and epithelial metaplasia of salivary ductus with consequent reduction in salivation and xerostomia. Due to lack of vitamin B, minor ulcers and hemorrhages may develop even in smaller oral traumas. The resistance to infection is reduced, and the appearance of the mucous membrane is often atrophic with exfoliation of the tongue papillae. Angular cheilitis, an inflammatory change in the corners of the mouth, is often present, which in the case of secondary infection may spread to the skin of the face [40, 41].

Vitamin B1 (thiamine) deficiency causes degeneration of peripheral nerves and consequently paresthesia of the oral mucosa, dysgeusia (taste disturbance), glossopyrosis (burning tongue) and stomatopyrosis (burning mouth). Oral symptoms caused by deficiency of vitamin B3, B4 and B6 are not characteristic and are manifested as stomatitis or glossitis with ulcerative and gingival lesions prone to hemorrhages [40, 45].

Vitamin B12 deficiency leads to pernicious anemia that manifests on the oral mucosa as Moller-Hunter's glossitis, characterized by a smooth and red tongue, atrophy of papillae and loss of taste sensation. Oral 
ulceration may occur, xerostomia, necrotizing ulcerative gingivitis, recurrent aphthous lesions and secondary candida infections. During advanced consequences of alcohol dependence the entire mucosa becomes atrophic with ulcerations covered with yellowish pseudomembranes [40, 45].

An important factor for growth and cell division involved in vitamin A resorption is folic acid. Its deficiency in the oral mucosa causes ulcerative and necrotizing ulcerative processes of the gingiva and palatal mucosa with inflammation of the tongue. Hypovitaminosis $\mathrm{C}$ is presented as scurvy which is clinically manifested by gingivitis with gingival tumor-like overgrowth and periodontal pockets that benefit further inflammation. Petechiae, ecchymosis, and ulcerative processes of the oral mucosa can appear associated with vitamin C deficiency [17]. Vitamin K deficiency causes disorders in prothrombin synthesis and hemorrhage and gingivitis of the oral mucous membrane. Iron deficiency is caused by hypochromic anemia, which presents as paleness of the mucous membrane, pain and burning sensation, gingival bleeding and tendency to erosion in the form of relapses of aphthae lesions. Along with iron deficiency Plummer-Vinson syndrome is often present, associated with sideropenic anemia, dysphagia and inflammatory changes of the tongue and gums with increased occurrence of oral premalignant lesions and cancer $[16,17]$.

\subsection{Oral mucosa changes connected with neurological illnesses caused by long- term alcohol drinking}

Alcohol epilepsy often leads to dental fractures as well as lip and tongue injuries during seizures. Anxiety and extensive muscular activity of the foot of the mouth muscles may appear in alcohol addicts. Additionally, oral parafunctions in the form of uncontrolled movements of the masticatory muscles and the tongue as well as biting of certain parts of the mucosa. These types of injuries often have complications in the form of secondary infections [17].

\subsection{Oral mucosa changes connected with immune system disorders caused by long-term alcohol drinking}

Damaged immune system function leads to vulnerability to invasion of microorganisms through the mucosa. Congruent with the gravity of the disorder, infections can develop a more or less serious clinical presentation. The most common acute candidiasis is pseudomembraneus candidiasis and most common chronic candidiasis is atrophic candidiasis [17].

\section{Conclusion}

Alcohol addiction affects health and it reflects on almost all organ systems. Effects on the oral cavity are various; from less serious disorders like inflammatory reactions, recurrent aphthae or heilitis, to more serious disorders like development of oral carcinoma. Effects on salivatory glands, reduced salivation and appearance of caries are scientifically proven to be causally linked to drinking alcohol, depending on the quantity and duration of drinking. In the literature, there is a clear connection between alcohol and development of carcinoma, especially if tobacco products are used together with extensive drinking. The cummulative effect of alcohol drinking and smoking of tobacco multiplies the risk of periodontitis, dental loss and oral carcinoma. Furthermore, alcohol causes dry mouth and reduces salivatory excretion which enables colonization of microorgan- 
isms and increases the risk of caries, exacerbated by a lack of oral hygiene in excessive alcohol drinkers.

It is worth stressing that changes in oral health can have serious consequences for an alcohol addict. Oral carcinoma has a high mortality rate even though it is located in a region which is easily accessible to regular clinical inspections. It is important to have in mind the risks of alcohol drinking, to conduct regular and detailed clinical examinations of people with ongoing alcohol ad-

\section{References}

1. Brezovec E. Consumption of Alcohol in Croatian Social Reality Alcohol as Part of Interaction Ritual Chain. Alcoholism and psychiatry research 2017;53:139-146.

2. Thaller V, Marušić S. Dijagnostičke i terapijske smjernice za liječenje alkoholom uzrokovanih poremećaja. Croatian Society for Alcoholism and other Addictions; [cited 2018 Dec 12]. Available from: https://www.hlz.hr/download/dijagnosticke-i-terapijske-smjernice-za-lijecenje-alkoholom-uzrokovanih-poremecaja/

3. Government of Republic of Croatia. National strategy for prevention of alcohol abuse and disorders caused by alcohol for the period 2011 - 2016. 2010 [cited 2018 Dec 8]. Available from: http://www.mzss.hr/layout/set/ print/ministarstvo/strategije_i_planovi/nacionalna_strategija_za_sprecavanje_stetne_uporabe_ alkohola_i_alkoholom_uzrokovanih_poremecaja_ za_razdoblje_od_2011_2016_godine

4. Cederbaum AI. Alcohol metabolism. Clin Liver Dis 2012;16:667-85.

5. Lotar Rihtarić M, Vrselja I, Jandrić Nišević A. Relationship between Alcohol Consumption and Violent Offending: Personality as a Contributing Factor. Alcoholism and psychiatry research 2016;52:105-114.

6. Žarković Palijan T, Saliral M, Kovačević D, Kovač M. Alcohol intoxication in drivers in road traffic diction or treated alcohol addicts, as well as continuing scientific efforts to expand the knowledge on all the effects of alcohol on the oral cavity.

\section{Acknowledgements}

None.

\section{Conflicts of interest}

None to declare. accidents and violations. Alcoholism and psychiatry research 2013;49:69-84.

7. Araujo MWB, Dermen K, Connors G, Ciancio S. Oral and dental health among inpatients in treatment for alcohol use disorders: a pilot study. J Int Acad Periodontol 2004;6:125-30.

8. Priyanka K, Sudhir KM, Reddy VCS, Kumar RK, Srinivasulu G. Impact of Alcohol Dependency on Oral Health - A Cross-sectional Comparative Study. J Clin Diagn Res JCDR 2017;11:ZC43-6.

9. Franceschi S, Talamini R, Barra S, Barón AE, Negri E, Bidoli E, et al. Smoking and drinking in relation to cancers of the oral cavity, pharynx, larynx, and esophagus in northern Italy. Cancer Res 1990;50:6502-7.

10. Maserejian NN, Joshipura KJ, Rosner BA, Giovannucci E, Zavras AI. Prospective study of alcohol consumption and risk of oral premalignant lesions in men. Cancer Epidemiol Biomark Prev Publ Am Assoc Cancer Res Cosponsored Am Soc Prev Oncol 2006;15:774-81.

11. Smith BG, Robb ND. Dental erosion in patients with chronic alcoholism. J Dent 1989;17:219-21.

12. DiFranza JR, Guerrera MP. Alcoholism and smoking. J Stud Alcohol 1990;51:130-5.

13. Llewellyn CD, Johnson NW, Warnakulasuriya KA. Risk factors for squamous cell carcinoma of the oral cavity in young people-a comprehensive literature review. Oral Oncol 2001;37:401-18. 
14. Scannapieco FA. Saliva-bacterium interactions in oral microbial ecology. Crit Rev Oral Biol Med 1994;5:203-48.

15. Homann N, Tillonen J, Meurman JH, Rintamäki $\mathrm{H}$, Lindqvist $\mathrm{C}$, Rautio $\mathrm{M}$, et al. Increased salivary acetaldehyde levels in heavy drinkers and smokers: a microbiological approach to oral cavity cancer. Carcinogenesis 2000;21:663-8.

16. Slocum C, Kramer C, Genco CA. Immune dysregulation mediated by the oral microbiome: potential link to chronic inflammation and atherosclerosis. J Intern Med. 2016;280:114-28.

17. Wade WG. The oral microbiome in health and disease. Pharmacol Res 2013;69:137-43.

18. Koren O, Spor A, Felin J, Fåk F, Stombaugh J, Tremaroli $\mathrm{V}$, et al. Human oral, gut, and plaque microbiota in patients with atherosclerosis. Proc Natl Acad Sci U S A 2011;108(Suppl 1):4592-8.

19. Jelić B, Vukić VA, Peco M, Vojnović D, Zoričić Z. Influence of oral health status on self esteem in patients with mental disorders - patients addicted to alcohol. Alcohol Psychiatry Res J Psychiatr Res Addict 2014;50:83-92.

20. O'Sullivan EM. Prevalence of oral mucosal abnormalities in addiction treatment centre residents in Southern Ireland. Oral Oncol 2011;47:395-9.

21. Jansson L. Association between alcohol consumption and dental health. J Clin Periodontol 2008;35:379-84.

22. Mandel L, Hamele-Bena D. Alcoholic parotid sialadenosis. J Am Dent Assoc 1997;128:1411-5.

23. Guggenheimer J, Close JM, Eghtesad B. Sialadenosis in Patients with Advanced Liver Disease. Head Neck Pathol 2009;3:100-5.

24. Dasanayake AP, Warnakulasuriya S, Harris CK, Cooper DJ, Peters TJ, Gelbier S. Tooth Tooth Decay in Alcohol Abusers Compared to Alcohol and Drug Abusers. Int J Dent 2010;786503.

25. Dukić W, Dobrijević TT, Katunarić M, Lesić S. Caries prevalence in chronic alcoholics and the relationship to salivary flow rate and $\mathrm{pH}$. Cent Eur J Public Health 2013;21:43-7.

26. Enberg N, Wolf J, Ainamo A, Alho H, Heinälä P, Lenander-Lumikari M. Dental diseases and loss of teeth in a group of Finnish alcoholics: a radiological study. Acta Odontol Scand 2001;59:341-7.
27. Wang J, Lv J, Wang W, Jiang X. Alcohol consumption and risk of periodontitis: a meta-analysis. J Clin Periodontol 2016;43:572-83.

28. Tezal M, Grossi SG, Ho AW, Genco RJ. The effect of alcohol consumption on periodontal disease. J Periodontol 2001;72:183-9.

29. Himmerich H, Anghelescu I, Klawe C, Szegedi A. Vitamin B12 and hepatic enzyme serum levels correlate in male alcohol-dependent patients. Alcohol Alcohol 2001;36:26-8.

28. Riedel F, Goessler UR, Hormann K. Alcohol-related diseases of the mouth and throat. Dig Dis Basel Switz 2005;23:195-203

29. Lewin F, Norell SE, Johansson H, Gustavsson P, Wennerberg J, Biörklund A, et al. Smoking tobacco, oral snuff, and alcohol in the etiology of squamous cell carcinoma of the head and neck: a population-based case-referent study in Sweden. Cancer 1998;82:1367-75.

30. Kil TJ, Kim HS, Kim HJ, Nam W, Cha I-H. Genetic Abnormalities in Oral Leukoplakia and Oral Cancer Progression. Asian Pac J Cancer Prev APJCP 2016;17:3001-6.

31. Shiu M-N, Chen TH-H. Impact of betel quid, tobacco and alcohol on three-stage disease natural history of oral leukoplakia and cancer: implication for prevention of oral cancer. Eur J Cancer Prev Off J Eur Cancer Prev Organ ECP 2004;13:39-45.

32. Villa A, Villa C, Abati S. Oral cancer and oral erythroplakia: an update and implication for clinicians. Aust Dent J 2011;56:253-6.

33. Bouquot JE. Oral leukoplakia and erythroplakia: a review and update. Pract Periodontics Aesthetic Dent PPAD 1994;6:9-17

34. Hashibe M, Mathew B, Kuruvilla B, Thomas G, Sankaranarayanan R, Parkin DM, et al. Chewing Tobacco, Alcohol, and the Risk of Erythroplakia. Cancer Epidemiol Prev Biomark 2000;9:639-45.

35. Blot WJ. Alcohol and cancer. Cancer Res 1992;52(7 Suppl):2119s-2123s.

36. Ogden GR. Alcohol and oral cancer. Alcohol Fayettev N 2005;35:169-73.

37. Goldstein BY, Chang S-C, Hashibe M, Vecchia CL, Zhang Z-F. Alcohol Consumption and Cancer of the Oral Cavity and Pharynx from 1988 to 2009: 
An Update. Eur J Cancer Prev Off J Eur Cancer Prev Organ ECP 2010;19:431-65.

38. Conway DI, Stockton DL, Warnakulasuriya K a. a. S, Ogden G, Macpherson LMD. Incidence of oral and oropharyngeal cancer in United Kingdom (1990-1999) -recent trends and regional variation. Oral Oncol 2006;42:586-92.

39. Reidy J, McHugh E, Stassen LFA. A review of the relationship between alcohol and oral cancer. Surg J R Coll Surg Edinb Irel 2011;9:278-83.

40. Cekić Arambašin A. Oralna medicina. Zagreb, Croatia: Školska knjiga; 2005
41. Burket LW, Greenberg MS, Glick M. Burket's Oral Medicine: Diagnosis \& Treatment. PMPH-USA; 2003. p. 680.

42. Maisch B. Alcoholic cardiomyopathy: The result of dosage and individual predisposition. Herz 2016;41:484-93.

43. Vodanovic M. Povišen krvni tlak i oralno zdravlje. Zdrav život 2008;7:41-5.

44. Cruz-Pamplona M, Jimenez-Soriano Y, SarrionPerez M. Dental considerations in patients with heart disease. J Clin Exp Dent 2011;97-105.

45. Hoyumpa AM. Mechanisms of vitamin deficiencies in alcoholism. Alcohol Clin Exp Res 1986;10:573-81.

\section{Učinci alkohola na oralno zdravlje}

Sažetak - Pijenje alkoholnih pića jedan je od najstarijih društveno prihvatljivih oblika ponašanja koji može dovesti do razvoja ovisnosti o alkoholu. Dugoročno pijenje alkohola ima, uz razne psihičke i somatske komplikacije, štetni utjecaj i na oralno zdravlje. Ovisnici o alkoholu imaju lošiju oralnu higijenu i neredovitu stomatološku skrb te se kod njih može naći više karijesnih lezija, gingivalnih bolesti, erozija, krvarenja interdentalnih papila i stvaranja dubokih gingivalnih džepova koji su povezani s gubitkom kostiju te veća stopa orofaringealnih karcinoma. Promjena u oralnom mikrobiomu ima posljedice i na imunološki sustav, probavu i metabolizam karcinogena što također dovodi do razvoja oralnih bolesti te sistemnih gastrointestinalnih i kardiovaskularnih bolesti. Štetno djelovanje alkohola na usnu šupljinu može biti direktno, uzrokovano lokalnim toksičnim učinkom alkohola ili posredstvom oštećenja drugih organskih sustava koji na taj način uzrokuju promjene cijele oralne sluznice. Loše prehrambene navike pridonose lošijem statusu usne šupljine, a istovremena upotreba duhanskih proizvoda dodatno povećava rizik nastanka periodontitisa, gubitka zuba i karcinoma usne šupljine. Dugotrajno pijenje alkohola može izazvati ozbiljne posljedice unutar usne šupljine o kojima, unatoč lakoj dostupnosti kliničkim pregledom, još uvijek nemamo dovoljno podataka niti u potpunosti razjašnjen mehanizam nastanka navedenih promjena.

Ključne riječi - alkohol, ovisnost o alkoholu, oralno zdravlje, bolesti usne šupljine 